\title{
The effects of monoclonal antibodies against iC3b receptors in mice with experimentally induced disseminated candidiasis
}

\author{
K. H. LEE, M. S. YOON \& W. H. CHUN Department of Dermatology and Institute for Immunology and Immunological Diseases, \\ Yonsei University College of Medicine, Seoul, Korea
}

\begin{abstract}
SUMMARY
CR3 (iC3b receptor), composed of $\mathrm{CD} 11 \mathrm{~b} / \mathrm{CD} 18$, is a $\beta_{2}$ integrin. A protein that shares antigenic and structural homology with the $\alpha$-chain of $\mathrm{CD} 11 \mathrm{~b} / \mathrm{CD} 18$ has been isolated from the surface of Candida albicans. This molecule is thought to be essential in the pathogenesis of disseminated candidiasis. To evaluate the effects of anti-iC $3 b$ receptor antibodies on adhesion between human dermal microvascular endothelial cells (HDMEC) and C. albicans, and in treatment of candidal infection, a binding assay of $C$. albicans to cultured HDMEC was performed in vitro. An antiiC3b receptor-specific monoclonal antibody was administered to mice infected with $C$. albicans. The mice were monitored for mortality and renal involvement by culture and histopathological findings. Flow cytometric analysis demonstrated surface expression of $\mathrm{iC} 3 \mathrm{~b}$ receptor on $C$. albicans. The adherence of $C$. albicans to HDMEC was significantly decreased by treatment with anti-iC3b receptor antibodies. Anti-iC3b receptor antibodies significantly increased the survival time and rate while lowering the renal fungal burden. The iC $3 \mathrm{~b}$ receptors are involved in the adherence of $C$. albicans to vascular endothelial cells and are likely to be involved in the pathogenesis of disseminated candidiasis. The increased survival in mice infected with $C$. albicans after treatment with anti-iC $3 \mathrm{~b}$ receptor antibodies indicates that this modality may be beneficial for future development of a new therapy for candidiasis.
\end{abstract}

\section{INTRODUCTION}

Adherence of a pathogen to host tissue is essential in the pathogenesis of infectious disease and presumably takes place in all forms of candidiasis. Studies concerning the modification or prevention of infection in relation to adhesion mechanisms have been performed in animal and human models. ${ }^{1,2}$ The virulence of a species of Candida can be correlated with its ability to adhere to various cell types, with the most virulent C. albicans being most adherent to epithelial cells. In animal models of invasive disease, the pathogenicities of candidal strains in vivo correlate directly with yeast adhesion in vitro. ${ }^{3}$ Endothelial attachment and subsequent penetration are requisite stages in the induction of haematogenously disseminated candidiasis.

Receptors [complement receptor (CR)1, CR2 and CR3] for $\mathrm{C} 3$ degradation fragments $(\mathrm{C} 3 \mathrm{~b}, \mathrm{iC} 3 \mathrm{~b}, \mathrm{C} 3 \mathrm{dg})$ are present

Received 14 January 1997; revised 14 May 1997; accepted 14 May 1997.

Abbreviations: CR, complement receptor; HDMEC, human dermal microvascular endothelial cell; HUVEC, human umbilical vein endothelial cell.

Correspondence: Dr K. H. Lee, Department of Dermatology, Yonsei University College of Medicine, C.P.O. Box 8044, Seoul, Korea. on many human cells operative in the immune and inflammatory host defence process and may be critical in the attachment of invading micro-organisms. ${ }^{3} \mathrm{C} 3$-binding structures are not specific for mammalian cells in general but can also be found in micro-organisms pathogenic for humans. CR3 is present on the surface of mammalian neutrophils, monocytes and phagocytes and has been known as CD11b/CD18, Mol, Mac-1, or iC3b receptor. It is composed of an $\alpha$-chain of $165000 \mathrm{MW}$ and a $95000 \mathrm{MW} \beta$-chain common to all leucocytes. There are $\mathrm{iC} 3 \mathrm{~b}$ receptors on the surface of $C$. albicans which share homology with the $\alpha$-chain of the neutrophilic receptors for iC 3 b. ${ }^{4-6}$ Western blotting and immunoprecipitation have confirmed the similar relative molecular weights of CR3 on the human neutrophil and the $\mathrm{iC} 3 \mathrm{~b}$ receptors isolated from $C$. albicans. $^{6,7}$

Since in disseminated candidiasis the fungus is delivered to target organs through the vascular system, targets for adherence of blood-borne fungi ultimately include the endothelial cell. Experiments on adhesion of $C$. albicans to cultured human umbilical vein endothelial cells (HUVEC) demonstrate that increasing glucose concentrations increase adhesion and monoclonal antibodies $(\mathrm{mAb})$ recognizing epitopes on neutrophil CR3 inhibit glucose-enhanced adhesion of $C$. albicans to HUVEC. $^{8}$ However, the exact role of $\mathrm{iC} 3 \mathrm{~b}$ receptors in haematogenously disseminated candidiasis in humans has not been elucidated. 
We assessed the role of $\mathrm{iC} 3 \mathrm{~b}$ receptors on $C$. albicans in the adhesion of yeast to cultured human dermal microvascular endothelial cells (HDMEC), and the inhibition of this adhesion by $\mathrm{mAb}$ against $\mathrm{iC} 3 \mathrm{~b}$ receptors. In addition, we observed the effects of intravenous injection of anti-iC $3 b$ receptor $\mathrm{mAb}$ with respect to mortality and long-term infection in mice with experimentally induced disseminated candidiasis.

\section{MATERIALS AND METHODS}

\section{Organisms}

One randomly selected pathogenic strain of $C$. albicans (American Type Culture Collection, Rockville, MD; ATCC 44808) recovered from human blood was used for these experiments. Yeast cells were grown to log-phase in Sabouraud's broth, as determined by colony counts and spectrophotometric measurement of OD at $420 \mathrm{~nm}$, and were then frozen at $-70^{\circ}$ until use. On the evening before the experiment, aliquots of frozen yeasts were inoculated into RPMI-1640 media (Gibco Laboratories, Grand Island, NY). After attaining log-phase growth, the yeasts were pelleted, washed three times with phosphate-buffered saline (PBS) and diluted spectrophotometrically to an OD of 0.5 at $420 \mathrm{~nm}$.

\section{Animals}

BALB/c mice (Daehan Laboratory Animal Research Centre, Seoul, Korea) weighing around $25 \mathrm{~g}$ were used for all experiments.

\section{Monoclonal antibodies}

Four $\mathrm{mAb}$ directed against epitopes on a subunit of CR3 were Mol (mouse IgM, Coulter Immunology, Hialeah, FL), 44 (mouse IgG1, R\&D Systems, Minneapolis, MN), Leu 5 (mouse IgG2a, Becton Dickinson, San Jose, CA), and M1/70. $\mathrm{M} 1 / 70$ (rat IgG2b) was purchased as a hybridoma (ATCC TIB 128) and was purified from supernatant by affinity chromatography on protein G-Sepharose (Hitrap Protein G column, Pharmacia Biotech, Uppsala, Sweden). The mAb ECCD-2 (anti-E-cadherin, rat IgG2a) was obtained from M. Takeichi (Kyoto University, Kyoto, Japan). ECCD-2 was purified from hybridoma supernatants by protein G-Sepharose affinity chromatography. MEM 48 (mouse IgG1, $\mathrm{R} \& \mathrm{D}$ Systems, Minneapolis, $\mathrm{MN}$ ) is a $\mathrm{mAb}$ directed against the common $\beta$-chain of CR3, leucocyte function associated antigen-1 (LFA-1).

\section{Flow cytometric analysis}

Fifty million colony-forming units (CFU)/ml of C. albicans were washed in PBS with $0.5 \%$ bovine serum albumin (BSA), counted and aliquotted for staining. Primary antibody at the appropriate dilution was added to each tube. Either an isotype control mAb or PBS without antibody was used as a first-step control with identical results. The cells were incubated for $30 \mathrm{~min}$ on ice, washed, and second-step antibody, diluted 1/20 in PBS with $0.5 \%$ BSA, was added. After another $30 \mathrm{~min}$ of incubation, the cells were washed and resuspended in $0.5 \mathrm{ml}$ PBS with $0.5 \%$ BSA. Propidium iodide was added immediately before flow cytometric analysis to identify dead cells. Fluorescence was examined by a Becton Dickinson FACStar flow cytometer (Becton Dickinson, Mountain View, CA) and expressed as log mean channel fluorescence.

\section{Isolation and culture of HDMEC}

HDMEC were isolated from human neonatal foreskins by trypsinization and Percoll gradient centrifugation as described previously. ${ }^{9,10}$ Briefly, foreskins were cut into small pieces, treated with $0 \cdot 3 \%$ trypsin (Sigma Chemical Co., St Louis, MD), and $1 \%$ ethylenediamine tetraacetic acid (EDTA; Sigma) and individual segments were compressed with a scalpel blade to express microvascular fragments. The microvascular segments were layered onto a $35 \%$ Percoll (Pharmacia AB, Sweden) gradient in Hank's balanced salt solution (HBSS) and spun at $400 \mathrm{~g}$ for $15 \mathrm{~min}$ at room temperature. The fraction with a density less than $1.048 \mathrm{~g} / \mathrm{ml}$ was applied to gelatin (Sigma) -precoated tissue-culture dishes and cultured in endothelial basal media (Clonetics Corp., San Diego, CA) with epidermal growth factor $1 \mathrm{ng} / \mathrm{ml}$ (Clonetics), hydrocortisone acetate $1 \mu \mathrm{g} / \mathrm{ml}$ (Sigma), dibutyryl cyclic AMP $5 \times 10^{-5} \mathrm{M}$ (Sigma), penicillin $100 \mathrm{U} / \mathrm{ml}$, streptomycin $100 \mu \mathrm{g} / \mathrm{ml}$, amphotericin B $250 \mu \mathrm{g} / \mathrm{ml}$ (Sigma), and 30\% human serum (Irvine Scientific, Santa Ana, CA). The resulting cell cultures were free of contaminating fibroblasts as assessed by expression of CD31 (Fig. 1) and uptake of acetylated low-density lipoproteins. Experiments were conducted with endothelial cells at passages $2-6$.

\section{Candida albicans-HDMEC adherence assay}

HDMEC were plated in gelatin-coated 96-well flat-bottomed culture plates. An isolate of $C$. albicans was grown in the RPMI medium, labelled with $\left[{ }^{35} \mathrm{~S}\right]$ methionine, washed extensively in PBS and resuspended in HBSS with calcium and magnesium, to which was added $1 \%$ BSA (BSA-HBSS ${ }^{++}$). Yeast cells were then held at $4^{\circ}$ to prevent germination before incubation with HDMEC $(5 \%$ germ tubes present for $C$. albicans). Then $4 \times 10^{4}$ CFU were added to each well of confluent HDMEC monolayer, and incubated for $1 \mathrm{hr}$ at $37^{\circ}$. For quantification of non-specific bindings, a 100 -fold excess of unlabelled yeast cells were added to labelled yeast cells. The supernatant was removed from each well and the monolayers washed twice with BSA-HBSS ${ }^{++}$to remove non-adherent yeasts. These were counted in a scintillation counter (Beckman Instruments, Inc., Palo Ato, CA). Adherent yeast cells and HDMEC monolayers were removed with $1 \%$ Triton-X (Sigma), then solubilized in $0.5 \mathrm{M} \mathrm{NaOH}$ and counted in a

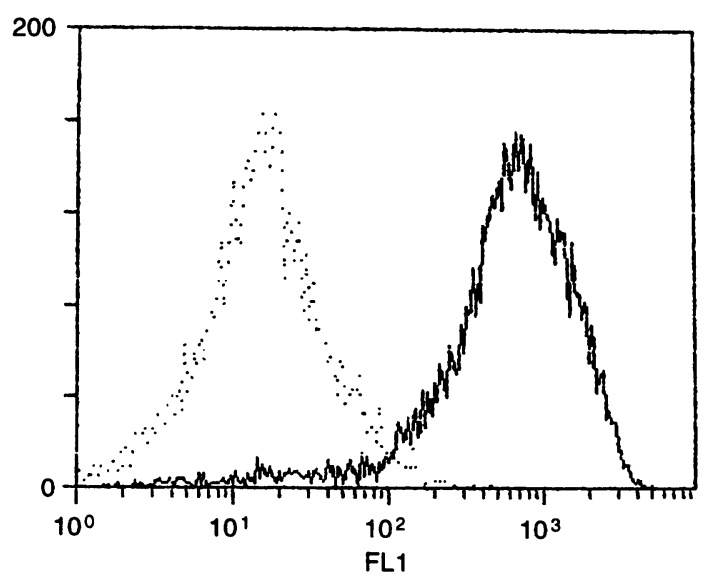

Figure 1. Flow-cytometric analysis showing the expression of CD31 on HDMEC. 
$\beta$-scintillation counter. The percentage binding of $C$. albicans was calculated as follows:

$$
\frac{\text { C.p.m. (adherent yeasts }- \text { non-specific binding) }}{\text { C.p.m. (total yeasts added }- \text { non-specific binding) }} \times 100 \text {. }
$$

\section{Inhibition of adhesion with $m A b$}

C. albicans was grown in RPMI medium and was then preincubated with $100 \mu 1$ of mAb to $\alpha$-subunit of CR3 for $45 \mathrm{~min} .100 \mu \mathrm{l}$ of $20 \mu \mathrm{g} / \mathrm{ml}$ of mAb were used. After preincubation with antibodies, the adherence assay was performed as described above in the continuous presence of antibodies. All the individual experiments were performed three times independently.

\section{Experimental infection}

Mice were divided into three experimental treatment groups for the assessment of anti-iC3b receptor antibody on the resulting prevention of systemic candidiasis. The three groups were: Group I, controls, received the vehicle for the $\mathrm{mAb}$ ( $0.5 \%$ human serum albumin) and was inoculated with one dose of $10^{6} \mathrm{CFU}$ of $C$. albicans grown in RPMI-1640 per mouse into the lateral tail veins of a group of 45 normal mice; Group II, mAb M1/70, beginning before infection received $\mathrm{mAb} \mathrm{M1/70} 2 \mathrm{mg} / \mathrm{kg}$ infused intravenously once per day for 5 days (day 0 to day 5). Group III, isotype control, beginning before infection received $\mathrm{mAb}$ ECCD-2 $2 \mathrm{mg} / \mathrm{kg}$ infused intravenously once per day for 7 days (day 0 to day 5); The fourth group received only equivalent amounts of $\mathrm{mAb} M 1 / 70$ at the same time. All animals were monitored for 30 days, and mortality was recorded. Two groups of 20 mice each were studied, an only $C$. albicans-inoculated group and a group treated anti-M1/70 $\mathrm{mAb}$ and inoculated with $C$. albicans as previously described. On days $0,2,4$ and 6 , five mice per experimental group were selected at random and killed by cervical dislocation. The kidneys of each of these animals were removed aseptically, transferred into sterile polyethylene bags, and homogenized in $5 \mathrm{ml}$ of sterile saline. Samples were removed from each homogenate, serially diluted in $0.9 \% \mathrm{NaCl}$, plated onto Sabouraud dextrose agar plates, and incubated at $25^{\circ}$ for $16 \mathrm{hr}$. The colonies were then enumerated, and CFU were calculated per gram of each organ. All experiments were performed in triplicate. To document the administration of M1/70 mAb sufficient to produce antibody excess, samples of serum were analysed for the presence of residual M1/70 antibody. Blood was collected from the orbital, venous plexus. This was assessed by indirect immunofluorescence analysis in which $C$. albicans were incubated in serum for $30 \mathrm{~min}$ at $25^{\circ}$, and then, after washing, incubated in fluorescein isothiocyanate (FITC)-conjugated goat anti-rat immunoglobulin for an additional $30 \mathrm{~min}$ at $25^{\circ}$. Antibody binding to $C$. albicans was quantified by flow cytometry. Formalin-fixed portions of kidneys obtained at 2, 4 and 6 days were stained with Periodic acid-Schiff reagent (PAS) to search for fungi in kidneys.

\section{Statistical analysis}

All data are expressed as mean \pm standard error. All differences in survival were analysed by the Wilcoxon rank sum test and Kruskal-Wallis test. Product limit method was used to analyse survival data and repeated ANOVA were applied to compare the mean CFU per mean kidney weight. Statistical significance was defined as a $P$-value of $<0.05$.

\section{RESULTS}

\section{Expression of iC3b receptor on $C$. albicans}

The iC3b receptor expression was observed by immunofluorescence flow cytometry from $C$. albicans pretreated with antiiC3b receptor antibody purified from culture supernatant of ATCC M1/70 antibody by affinity chromatography (Fig. 2).

\section{Effect of anti-iC3b receptor antibody on adhesion of $C$. albicans to HDMEC}

Preliminary studies were done to compare the rate of adhesion between HDMEC and $C$. albicans according to the number of C. albicans and elapsed time. The binding of $5 \times 10^{5} \mathrm{CFU}$, $1 \times 10^{6} \mathrm{CFU}$ and $2 \times 10^{6} \mathrm{CFU}$ of $C$. albicans to HDMEC were $25 \cdot 1 \pm 3 \cdot 8 \%, 29 \cdot 9 \pm 2 \cdot 2 \%$ and $28 \cdot 3 \pm 1 \cdot 5 \%$, respectively. The adherences $30 \mathrm{~min}, 1 \mathrm{hr}$ and $2 \mathrm{hr}$ after culture were $8 \cdot 1 \pm 1 \cdot 9 \%$, $24 \cdot 1 \pm 3 \cdot 7 \%$ and $25 \cdot 4 \pm 4 \cdot 9 \%$. The adherence increased significantly after $1 \mathrm{hr}$ of culture. Further studies were carried out under culture conditions with $10^{6} \mathrm{CFU}$ of $C$. albicans being cultured for $1 \mathrm{hr}$.

The adhesion of $C$. albicans without any prior treatment to HDMEC was $24 \cdot 0 \pm 3.6 \%$. Adherences were $25 \cdot 4 \pm 5 \cdot 4 \%$, $27 \cdot 9 \pm 1 \cdot 8 \%, 26 \cdot 3 \pm 0 \cdot 3 \%$ and $16 \cdot 5 \pm 2 \cdot 2 \%$ when $C$. albicans was treated before inoculation with rat IgG2b, mAb ECCD-2, anti-CD18, and M1/70 mAb, respectively (Fig. 3).

\section{Effect of anti-iC3b receptor antibody on mortality in mice with experimentally induced disseminated candidiasis}

Preliminary studies were performed to determine the mortality rates of $\mathrm{BALB} / \mathrm{c}$ mice according to the number of $C$. albicans. All mice injected with $5 \times 10^{6} \mathrm{CFU}$ of $C$. albicans cultured in RPMI-1640 media expired within 1 day. At $1 \times 10^{6} \mathrm{CFU}$ and $5 \times 10^{5} \mathrm{CFU}$, the average survival durations were $2 \cdot 7 \pm 0.6$ days and $4 \cdot 3 \pm 0.6$ days, respectively. Inoculation was done with $1 \times 10^{6} \mathrm{CFU}$ of $C$. albicans to determine mortality and effects of the anti-iC3b receptor antibodies. Group I was inoculated with only $C$. albicans. Group II was pretreated with
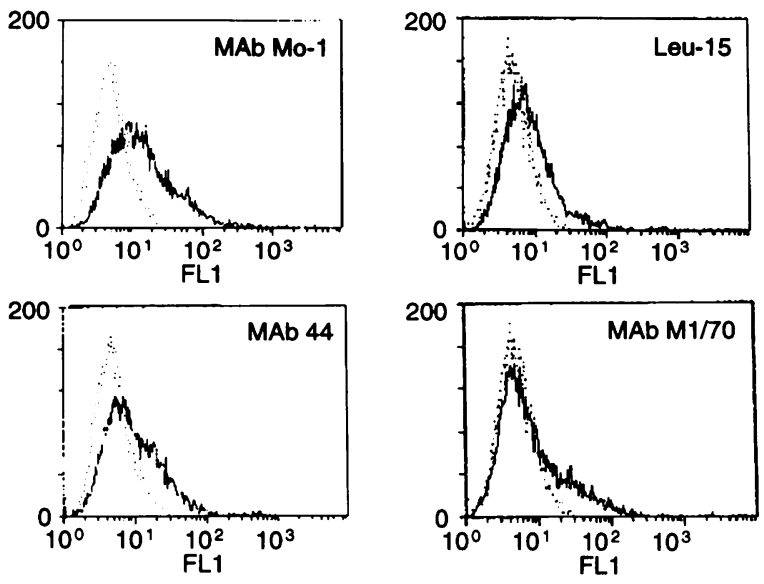

Figure 2. Expression of $\mathrm{iC} 3 \mathrm{~b}$ receptor on the surface of $C$. albicans. Candida albicans was incubated with anti-iC3b receptor $\mathrm{mAb}$ antiMo1, Leu5, 44 and M1/70 and analysed by fluorescence-activated cell sorter. The expression of iC3b receptors can be observed on the surface of $C$. albicans. 


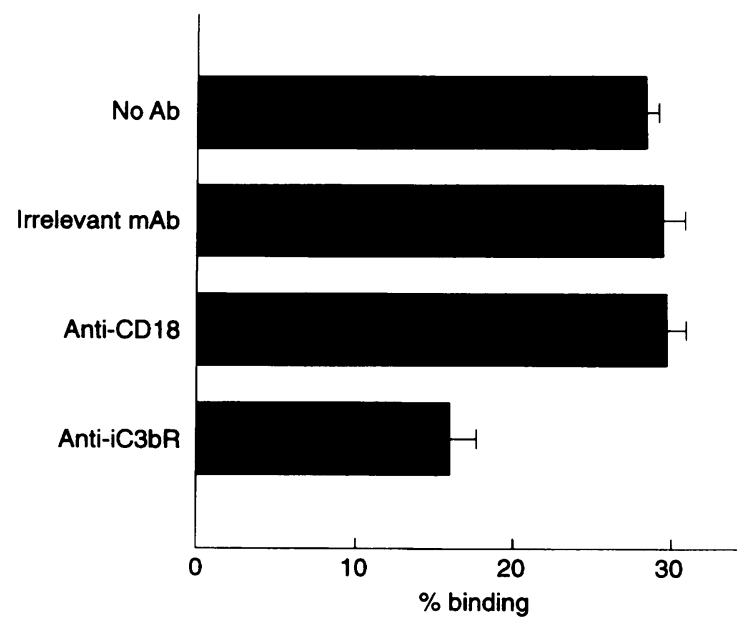

Figure 3. The effects of anti-iC3b receptor antibodies on the adhesion of $C$. albicans to HDMEC. Candida albicans was pretreated with irrelevant antibody ECCD-2, mAb anti-CD18 against the $\beta$-chain of iC $3 \mathrm{~b}$ receptor, and $\mathrm{M} 1 / 70$ against the $\alpha$-chain of $\mathrm{iC} 3 \mathrm{~b}$ receptor, added in concentrations of $20 \mu \mathrm{g} / \mathrm{ml}$ at $37^{\circ}$ for $45 \mathrm{~min}$, and incubated with HDMEC monolayer at $37^{\circ}$ for $1 \mathrm{hr}$. Results show the mean percentage \pm SD of quadruplicate microtitre wells.

$\mathrm{M} 1 / 70 \mathrm{mAb} 1 \mathrm{hr}$ prior to inoculation with $C$. albicans and Group III was pretreated with mAb ECCD-2 $1 \mathrm{hr}$ prior to inoculation with $C$. albicans as control. Immunofluorescence studies revealed strong fluorescence on the surface of $C$. albicans collected from the serum of mice 6 days after the initial inoculation of M1/70 mAb. Fluorescence was observed on the surface of $C$. albicans by immunofluorescent flow cytometry from serum collected 2, 4 and 6 days after inoculation.

Group IV was injected with only anti-iC3b antibodies and all 45 mice were alive 30 days after injection. However, all 45 mice in both Group I and Group III expired between 2 and 5

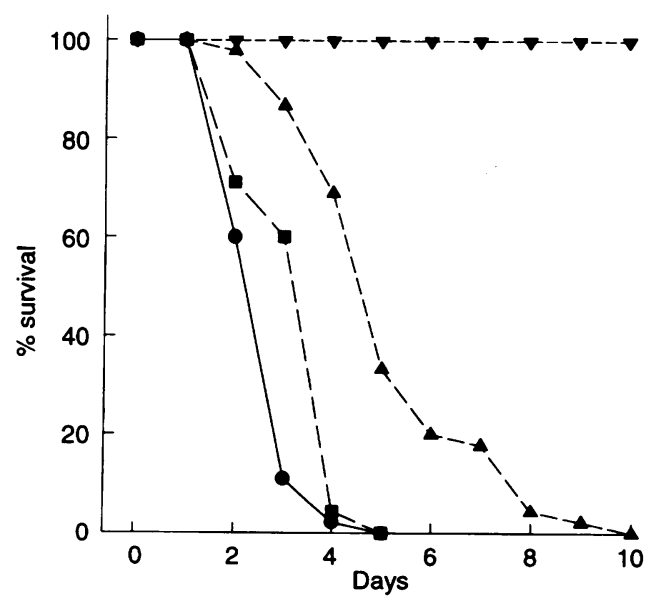

Figure 4. Effect of anti-iC3b receptor antibody on mortality of mice with experimentally induced disseminated candidiasis. Group I was inoculated with only $C$. albicans $(\bullet)$. Group II was inoculated with C. albicans and intravenously injected with anti-iC3b receptor antibody $\mathrm{M} 1 / 70$ at $2 \mathrm{mg} / \mathrm{kg}(\mathbf{\Delta})$. Group III was intravenously injected with $\mathrm{mAb}$ ECCD-2 at $2 \mathrm{mg} / \mathrm{kg}$ and inoculated with $C$. albicans $(\boldsymbol{\square})$. Group IV was injected with only anti-iC3b receptor antibody $M 1 / 70(\nabla)$. The mortality and survival duration of the four groups were compared.
Table 1. Effect of anti-iC $3 b$ receptor antibody on duration of survival in mice with experimentally induced disseminated candidiasis

\begin{tabular}{lcc}
\hline Inoculation group & $\begin{array}{c}\text { No. of } \\
\text { animals }\end{array}$ & $\begin{array}{c}\text { Survival duration } \\
\text { (days) }\end{array}$ \\
\hline C. albicans only* & 45 & $2 \cdot 7 \pm 0 \cdot 7$ \\
C. albicans + mAb M1/70 $\dagger$ & 45 & $5 \cdot 3 \pm 1 \cdot 8$ \\
C. albicans + control mAb $\ddagger$ & 45 & $3 \cdot 4 \pm 0 \cdot 9$ \\
mAb M1/70 only $\$$ & 45 & $>30$ \\
\hline
\end{tabular}

*Group I was inoculated with only $C$. albicans.

†Group II was inoculated with $C$. albicans and intravenously injected with anti-iC3b receptor antibody $\mathrm{Ml} / 70$ at $2 \mathrm{mg} / \mathrm{kg}$ of concentration.

†roup III was intravenously injected with mAb ECCD-2 at $2 \mathrm{mg} / \mathrm{kg}$ of concentration and inoculated with $C$. albicans.

$\S$ Group IV was injected with only anti-iC3b receptor antibody M1/70.

days after inoculation. All mice in Group II expired between 2 and 10 days after inoculation. However, the mortality rate in Group II at 4 days after inoculation was $31 \cdot 1 \%$, which was significantly lower than the mortality rates at this time in Groups I and III ( $P=0.0001$, Fig. 4$)$. The average survival durations for Groups I, II and III were $2 \cdot 7 \pm 0 \cdot 7$ days, $5 \cdot 3 \pm 1 \cdot 8$ days, and $3 \cdot 4 \pm 0.9$ days, respectively, (Table 1 ). These differences were significant. White blood cell counts and morphology of mouse neutrophils were not different between the irrelevant mAb-treated group and the M1/70-treated group.

Effect of anti-iC3b receptor antibody on renal invasion of $C$. albicans in mice with experimentally induced disseminated candidiasis

To evaluate the effects of anti-iC3b receptor antibody in disseminated candidiasis, mice were injected intravenously with $5 \times 10^{5} \mathrm{CFU}$ of $C$. albicans cultured in RPMI-1640. The mice were killed at random and the kidneys were removed, homogenized and cultured on a Sabouraud dextrose agar plate.

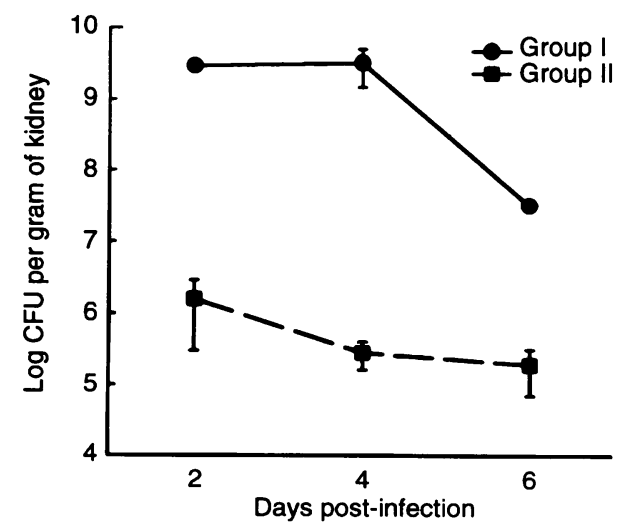

Figure 5. Effect of anti-iC3b receptor antibody on renal invasion of mice with experimentally induced disseminated candidiasis. Group I was inoculated with only $C$. albicans. Group II was inoculated with C. albicans and intravenously injected with anti-iC $3 \mathrm{~b}$ receptor antibody M1/70 at $2 \mathrm{mg} / \mathrm{kg}$. Renal specimens were harvested every 2 days for 6 days to evaluate the invasion of kidneys. A quantitative culture assay was performed three times for each mouse. The average CFU of C. albicans/g of kidney were compared. 
(a)
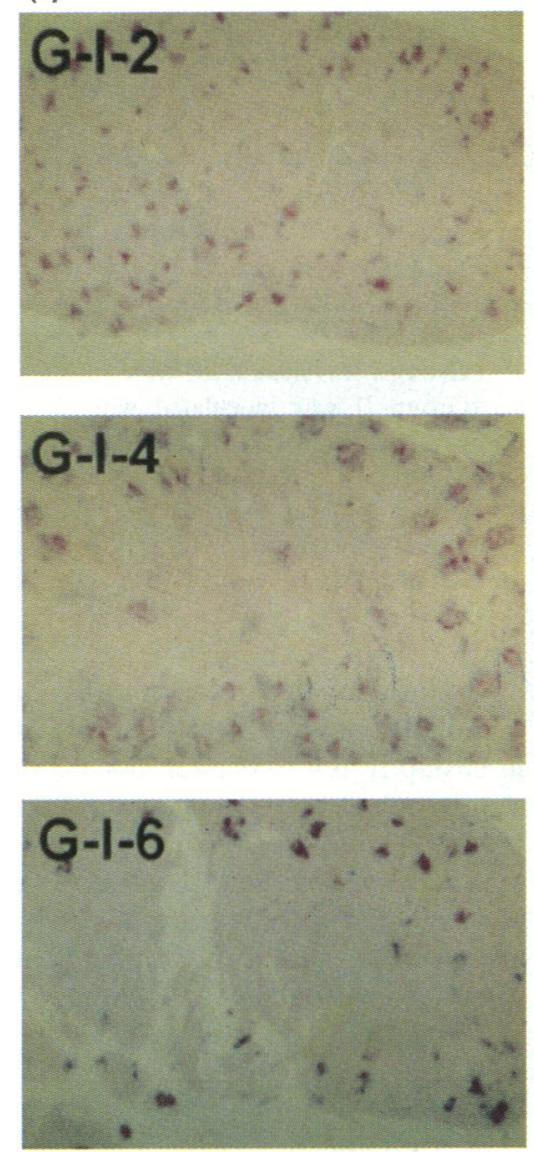

(b)
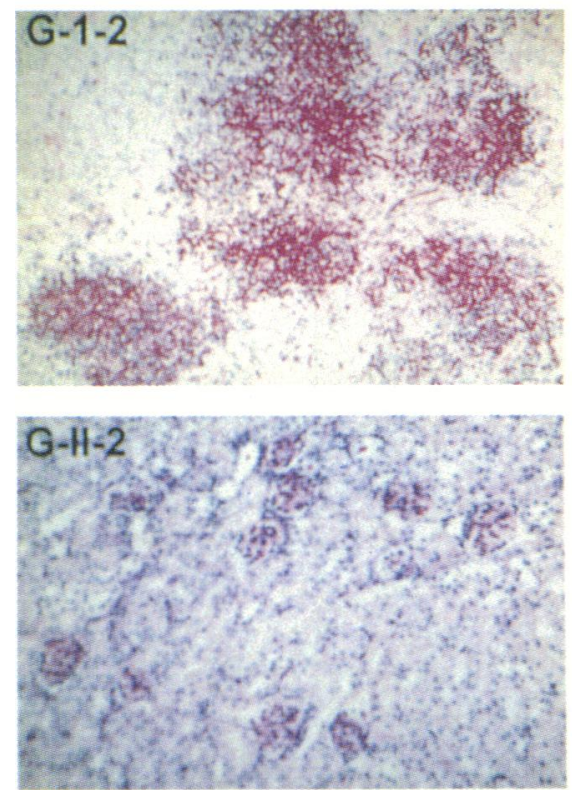
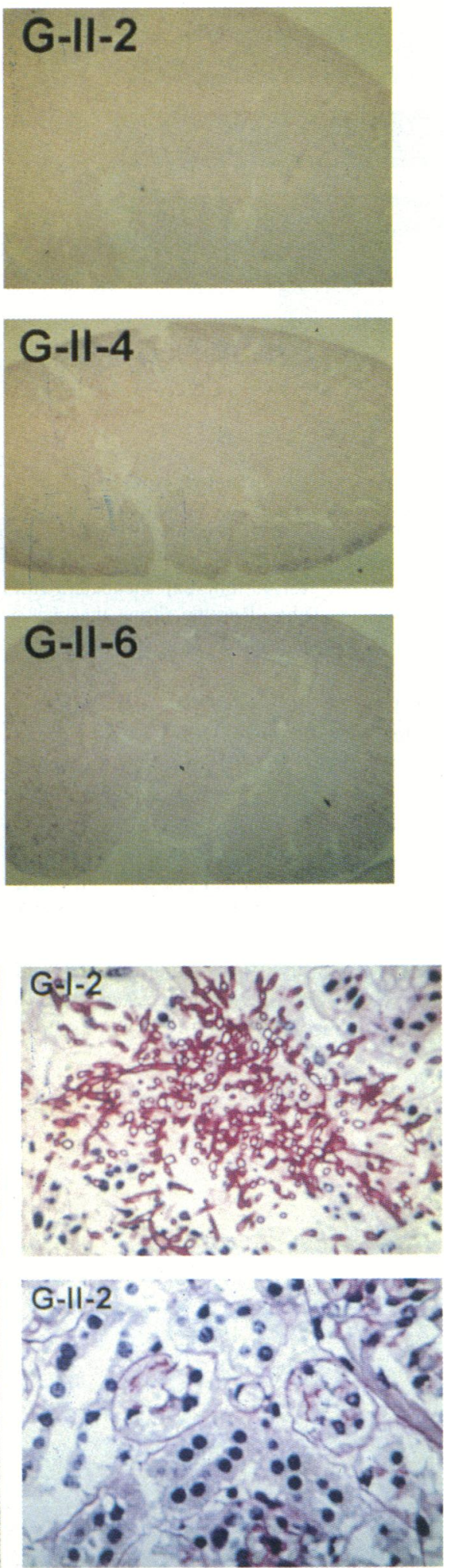

Figure 6. (a) Histopathological findings of kidney of mice with experimentally induced disseminated candidiasis and treated with anti-iC3b receptor antibody (PAS stain $\times 40)$. (b) Higher magnification $(\times 400)$. Group I was inoculated with only $C$. albicans. Group II was inoculated with $C$. albicans and intravenously injected with anti-iC3b receptor antibody M1/70 at $2 \mathrm{mg} / \mathrm{kg}$. Renal specimens were harvested every 2 days for 6 days to evaluate the invasion of kidneys. Specimens were paraffin-embedded and stained with periodic Schiff reagent. This staining revealed many fungal spores and hyphae in the glomerulus at the second day of infection in Group I, whereas Group II showed only few fungal spores and hyphae. G-I-2, Group I-day 2; G-I-4, Group I-day 4; G-I-6, Group I-day 6; G-II-2, Group II-day 2; G-II-4, Group II-day 4; G-II-6, Group II-day 6. 
On the days 2, 4 and 6 of infection, Group I had $3.0 \pm 0.2 \times 10^{9} \mathrm{CFU}, 3.3 \pm 1.8 \times 10^{9} \mathrm{CFU}, 3 \cdot 2 \pm 0 \cdot 1 \times 10^{7} \mathrm{CFU}$ of $C$. albicans, respectively, in $1 \mathrm{~g}$ of kidney. By comparison, Group II had $1.6 \pm 1.3 \times 10^{6} \mathrm{CFU}, 2.8 \pm 1.2 \times 10^{5} \mathrm{CFU}$, $1.9 \pm 1.2 \times 10^{5} \mathrm{CFU}$ of $C$. albicans, respectively, in $1 \mathrm{~g}$ of kidney. These differences in renal involvement were statistically significant $(P=0.0001$, Fig. 5).

Periodic acid-Schiff staining of the extracted renal specimens revealed many fungal spores and hyphae in the renal medulla on day 2 of infection in Group I. Group II showed only a few fungal spores and hyphae on day 2 of infection. Group I showed heavy infiltration of inflammatory cells at the sixth day of infection (Fig. 6).

\section{DISCUSSION}

The importance of the adherence of Candida in the pathogenesis of disseminated disease is increasingly recognized. There have been reports that pathogenicity of candidal strains in vivo correlate directly with yeast adhesion in vitro. ${ }^{3}$ However, studies on fungus-to-host cell adhesion mechanisms have been relatively sparse. It is possible to categorize these adhesion mechanisms by considering the components of each ligandreceptor. ${ }^{11}$ The first category includes protein-protein interactions such as the iC $3 \mathrm{~b}$ receptor on $C$. albicans. The second category includes interactions in which a surface Candida protein with lectin activity recognizes sugar residues associated with the host-cell plasma membrane. The third category involves a carbohydrate ligand, mannan, on the Candida cell surface that is recognized by an unknown host-cell receptor. Complement fragments adhere more readily to Candida than to endothelial cells in vitro. ${ }^{4,12} \mathrm{CR} 3$ on neutrophils is involved in recognition of $\mathrm{iC} 3 \mathrm{~b}$ on the surface of micro-organisms and subsequent phagocytosis. The $\mathrm{iC} 3 \mathrm{~b}$ receptor on the surface of C. albicans has recently been isolated and characterized. ${ }^{13}$ The iC $3 \mathrm{~b}$ receptor in Candida shares antigenic and structural homology with CR3 on neutrophils. ${ }^{4-6}$

As we, and others, have observed the expression of iC $3 b$ receptor is usually below $50 \%$ depending on the type of $\mathrm{mAb}$ used, condition of culture medium, species or strains of Candida used, etc. ${ }^{5,6,8,12}$ The low expression in our study was due to the RPMI medium with low glucose concentration. When the glucose concentration was increased, the expression of $\mathrm{iC} 3 \mathrm{~b}$ receptor was up-regulated (unpublished results). However, the difference in the expression could be attributed to the type of mAb used.

The relationship between hyperglycaemia and candidal infection has been well documented. ${ }^{14}$ However, the exact mechanism by which sensitivity to candidal infection is increased is unknown. There have been reports that expression of $\mathrm{iC} 3 \mathrm{~b}$ receptor on Candida and adhesion to cultured HUVEC correlate with glucose concentrations. ${ }^{5,6}$ Moreover, adhesion to cultured HUVEC is suppressed by $50-80 \%$ with $\mathrm{mAb}$ directed against the $\alpha$-chain of the iC $3 \mathrm{~b}$ receptor. ${ }^{8}$

As there are marked differences between the endothelial cells of various vessels, ${ }^{9,10,15}$ and as $C$. albicans infects the skin and mucous membranes easily, we performed adhesion experiments using cultured HDMEC isolated from skin. Our results show that adherence of $C$. albicans correlates with reaction time and number of organisms. But there was a marked decrease when anti-iC $3 b$ receptor $\mathrm{mAb}$ were added. These findings are similar to previous studies using HUVEC. ${ }^{8}$

Intercellular adhesion molecule-1 (ICAM-1), which acts as a ligand for neutrophil CR3, has no role in the adhesion of iC 3 b receptor on C. albicans. ${ }^{8,16}$ Recently, the host ligand for the iC $3 \mathrm{~b}$ receptor on $C$. albicans has been characterized as iC $3 b .{ }^{17} \mathrm{C} 3$ is synthesized from endothelial cells ${ }^{18}$ and it is plausible to assume that $\mathrm{C} 3$ is degraded by proteolytic enzymes in the serum or cell with the resultant iC $3 \mathrm{~b}$ attaching to the endothelial surface and acting as a ligand for the iC $3 \mathrm{~b}$ receptor. ${ }^{7,18,19}$

In the present study, binding of C. albicans to HDMEC was partially inhibited by $\mathrm{mAb} M 1 / 70$. This would be explained by the finding of $50000,100000,130000$ and 165000 MW proteins in extracts of $C$. albicans reacting with anti-iC3b receptor antibodies in immunoblotting and immunoprecipitation studies. ${ }^{6,7}$ Hence, the combination of this variability of the $\mathrm{iC} 3 \mathrm{~b}$ receptor epitopes and specificity of each $\mathrm{mAb}$ might have resulted in the partial inhibition as seen in our study.

We confirmed that the iC 3 b receptor on C. albicans is essential for adhesion to cultured HDMEC. Thus we assumed that prevention of the yeast-to-host cell adhesion could block the dissemination of Candida to surrounding tissue. haematogenously disseminated candidiasis was induced in mice by intravenous injection with $C$. albicans. The mortality rate of the group injected with anti-iC3b receptor mAb was significantly lower than that of the normal control. The $50 \%$ survival rate increased significantly. The amount of yeast and the extent of invasion of renal tissue was significantly less. The affinity constant for the $\mathrm{iC} 3 \mathrm{~b}$ receptor is $2 \cdot 1 \pm 0.5 \times 10^{6} \mathrm{~L} / \mathrm{M}$ for human neutrophils ${ }^{20}$ and virtually identical to that of $C$. albicans. ${ }^{5}$ However, Candida possess $2 \times 10^{6}$ iC $3 \mathrm{~b}$ receptors per yeast which is nearly 100 times higher than neutrophils. ${ }^{5}$ The increased survival rate in mice treated with anti-iC $3 \mathrm{~b}$ receptor antibodies indicates that this modality might be beneficial for future development of a new therapy for disseminated candidiasis.

The $\mathrm{iC} 3 \mathrm{~b}$ receptor on Candida is homologous in srtucture to human CR3, however, it is not the same molecule. There is no doubt that antibodies directly against the Candida $\mathrm{iC} 3 \mathrm{~b}$ receptor would be likely to bind better to Candida and to have better inhibitory effects. However, at this time, we could not obtain the purified candidal iC $3 \mathrm{~b}$ receptor and its mAb. It is desirable that similar experiments using the above antibody be carried out as a next step to evaluate the clinical usefulness of anti-iC3b receptor antibody in the treatment of haematogenous candidiasis.

The anti-iC3b receptor $\mathrm{mAb}$ may have deleterious effects on host neutrophils and aggravate the course of disease, but our in vivo results indicate that they have a therapeutic effect in haematogenously disseminated candidiasis without significant alterations in host neutrophils. Attachment to the $\mathrm{iC} 3 \mathrm{~b}$ receptor on C. albicans blocks adhesion to endothelium and subsequent systemic invasion. Adherence to the endothelium is correlated with virulence. However, it is too early to discuss the interactions between intravenously injected $C$. albicans and the anti-iC3b receptor mAb based solely on the current experiment. We plan to use radioisotope-labelled anti-iC3b antibodies for future studies and to evaluate the safety profiles of anti-iC $3 \mathrm{~b} \mathrm{mAb}$ in humans. 


\section{ACKNOWLEDGMENTS}

The authors thank Dr Masatoshi Takeichi (Kyoto University, Kyoto, Japan) for providing ECCD-2 mAb. We are also grateful for the expert technical assistance of Nam Soo Jang. This paper was supported in part by the Non-Directed Research Fund, Korea Research Foundation., Korea.

\section{REFERENCES}

1. BEACHY E.H. (1981) Bacterial adherence: adhesion-receptor interactions mediating the attachment of bacteria to mucosal surfaces. $J$ Infect Dis 143, 325.

2. FRETER R. \& Jones G.W. (1983) Models for studying the role of bacterial attachment in virulence and pathogenesis. Rev Infect Dis 5, s647.

3. Scheld W.M., Strunk R.W., Balian G. \& Calderone R.A. (1985) Microbial adhesion to fibronectin in vitro correlates with production of endocarditis in rabbits. Proc Soc Exp Biol Med $180,474$.

4. EdWARDS J.E. JR., Gaither T.A., O'ShEA J.J. et al. (1986) Expression of specific binding sites on Candida with functional and antigenic characteristics of human complement receptors. $J$ Immunol 137, 3577.

5. Gilmore B.J., Retinas E.M., Lorenz J.S. \& Hostetter M.K. (1988) An iC3b receptor on Candida albicans: structure, function, and correlates for pathogenicity. $J$ Infect Dis 157, 38.

6. Hostetter M.K., Lorenz J., Preus L. \& Kendrick K.E. (1990) The iC3b receptor on Candida albicans: subcellular localization and modulation of receptor expression by glucose. $J$ Infect Dis 161, 761 .

7. Eigentler A., Schulz T.F., Larcher C. et al. (1989) C3bibinding protein on Candida albicans: temperature-dependent expression and relationship to human complement receptor type 3. Infect Immun 57, 616 .

8. Gustafson K.S., Vercellotti G.M., Bendel C.M. \& Hostetter M.K. (1991) Molecular mimicry in Candida albicans: role of an integrin analogue in adhesion of the yeast to human endothelium. J Clin Invest 87, 1896.

9. LeE K.H., LAWLeY T.J., Xu Y.\& Swerlick R.A. (1992) VCAM-1,
ELAM-1, and ICAM-1-independent adhesion of melanoma cells to cultured human dermal microvascular endothelial cells. $J$ Invest Dermatol 98, 79.

10. Swerlick R.A., Lee K.H., Li S.J., CaughmanN S.W. \& Lawley T.J. (1992) Regulation of vascular cell adhesion molecule 1 on human dermal microvascular endothelial cells. J Immunol 149, 698.

11. Calderone R.A. \& Braun P.C. (1991) Adherence and receptor relationships of Candida albicans. Microbiol Rev 55, 1.

12. Heidenreich F. \& Dierich M.P. (1985) Candida albicans and Candida stellatoidea in contrast to other Candida species, bind iC3b and C3d but not C3b. Infect Immun 50, 598.

13. Alaei S., Larcher C., Ebenbichler C., Prodinger W.M., JANATOVA J. \& DiERICH M.P. (1993) Isolation and biochemical characterization of the $\mathrm{iC} 3 \mathrm{~b}$ receptor of Candida albicans. Infect Immun 61, 1395.

14. Horn R., Wong B., KieHn T.E. \& Armstrong D. (1985) Fungemia in a cancer hospital: changing frequency, earlier onset and results of therapy. Rev Infect Dis 7, 646.

15. Swerlick R.A LeE K.H., Wick T.M \& LaWley T.J. (1992) Human dermal microvascular endothelial but not human umbilical vein endothelial cells express CD36 in vivo and vitro. J Immunol 148, 78.

16. Lo S.K., van SeVenter G.A., Levin S.M. \& Wright S.D. (1989) Two leukocyte receptors (CD1 1a/CD18 and CD1 1b/CD18) mediate transient adhesion to endothelium by binding to different ligands. J Immunol 143, 3325.

17. Bendel C.M. \& HosteTter M.K. (1993) Distinct mechanisms of epithelial adhesion for Candida albicans and Candida tropicalis. $J$ Clin Invest 92, 1840.

18. Brooimans R.A., van der Ark A.A., BuUrman W.A., van Es L.A. \& DAHA M.R. (1990) Differential regulation of complement factor $\mathrm{H}$ and $\mathrm{C} 3$ production in human umbilical vein endothelial cells by IFN- $\gamma$ and IL-1. J Immunol 144, 3835.

19. Wright S.D., Reddy P.A., Jong M.C.T. \& ERICKSON B.W. (1987) C3bi receptor (complement receptor type 3) recognizes a region of complement protein $\mathrm{C} 3$ containing the sequence ArgGly-Asp. Proc Natl Acad Sci USA 84, 1965.

20. Gordon D.L., Johnson G.M. \& Hostetter M.K. (1987) Characteristics of iC $3 \mathrm{~b}$ binding to human polymorphonuclear leukocytes. Immunology 60, 553. 